\title{
Community Based Education Planning
}

\author{
Nasrudin $^{1)}$, Sutaryat Trisnamansyah ${ }^{2)}$, Iim Wasliman ${ }^{3)}$, Hendi Suhendraya $^{4)}$ \\ 1) STAI PUI Majalengka \\ 2,3,4) UNINUS Bandung \\ *Coresponding Author \\ Email : nasrudinwardah@gmail.com
}

\begin{abstract}
Planning is an important and strategic element and provides direction in the implementation of activities to achieve the desired goals or objectives. The focus of this research is community-based education planning which is detailed in research problems, namely curriculum implementation planning and academic planning. This study uses a qualitative approach with data collection techniques including interviews, observations, and documentation studies. Technique of data validity with source triangulation. The data analysis uses the following procedures: data reduction, data presentation, and drawing conclusions. Research results: The curriculum applied at PKBM Miftahul Huda Majalengka uses a mixed curriculum or modification of the national curriculum combined with the Miftahul Huda Majalengka Taklim Council curriculum. The curriculum implementation planning has been made by the teacher. To support the implementation of the curriculum, an academic plan is made. The special academic planning in PKBM Miftahul Huda Majalengka is the Preparatory Class. Suggestions that can be given: (1) So that every teacher makes a complete curriculum implementation plan. (2) Recruitment of teaching staff according to their specialization.
\end{abstract}

\section{Keywords: Mangement, Community Based Learning.}

\section{INTRODUCTION}

The quality and results of education have not fully met the expectations and needs of the community, therefore the role of the community in advancing education is very necessary. One of the important platforms adopted in the framework of national education reform is the development of community-based education (Community Based Education).

In the General Provisions of Law No. 20/2003 article 1 paragraph 16 it is explained that the meaning of community-based education is the implementation of education based on religious, social, cultural characteristics, aspirations, and community potential as the embodiment of education from, by, and for the community. Galbraith (1995) defines community-based education as an educational process in which individuals or adults become more competent in their skills, attitudes, and concepts in an effort to live and control local aspects of their society through democratic participation. To realize the empowerment of education, PKBM also has the obligation to prepare planning activities. One form of educational planning is curriculum development planning.

Curriculum development is carried out through three stages, namely planning, implementation, and evaluation of the operational curriculum. In any field, planning is an important and strategic element and provide direction in the implementation of activities to achieve the desired goals or objectives. In the field of education, planning is one of the key factors in the effectiveness of implementing educational activities to achieve the expected educational goals. To support the successful implementation of the curriculum that has been prepared, it is also necessary to have academic planning. This academic planning includes a program of activities, academic calendar. lesson schedule, setting assignments and teacher 
obligations. With academic planning which outlines the four fields, it is hoped that the implementation of the curriculum can achieve maximum results.

Planning will produce plans. In this regard, educational planning is a process of educational activities while educational plans are the result of a jointly determined plan. Educational planning is a continuous intellectual process in analyzing, formulating, weighing, and making decisions that are consistent and relate systematically to other decisions (Sarbini and Lina, 2011: 30). Meanwhile, other education experts explain that educational planning is a rational application of a systematic analysis of the educational development process with the aim that education is more effective and efficient and in accordance with the needs and goals of students and their community (Sa'ud and Makumun, 2009: 8 ).

Thus it can be said that educational planning is a process of activities to prepare for the future that is rational and systemic in terms of determining policies, priorities and costs of education effectively and efficiently to achieve the goals that have been set based on needs. Community-based education centers on students' ability to recognize and support the needs of the local community. Society and students. (Villiani and Atkins, 2008), while according to the 1945 Constitution it is stated that community-based education is the implementation of education based on the uniqueness of religion, social, culture, aspirations, and potential, the community as the embodiment of education from, by, and for the community. (Law No. 20 2003, Chapter I, art. 1). The point is that community-based education is education from the community, by the community, and for the community. Implementation includes three main things including (1) program development including annual, semester, or quarterly, monthly, weekly, daily programs, and there is also counseling guidance. (2) the implementation of learning in essence, learning is an intellectual process between students and the environment, so that changes in behavior occur for the better. (3) evaluation of learning carried out throughout the running curriculum. (Hamalik, 2008: 308). Meanwhile, Sudarsyah and Nurdin (2011: 196) are slightly different from Hamalik regarding the stages of curriculum implementation. They divide the stages of curriculum implementation into four stages, namely; planning, organizing and coordinating, implementing, and controlling. Planning, including planning for curriculum implementation, is made to have the intention or purpose of explaining at least four planning functions, namely planning to function as a direction, minimizing the impact of change, minimizing waste and waste, and setting quality control standards. (Robbins and Coulter in Sule and Saefullah (2010: 97). To facilitate the implementation of the curriculum, it is also necessary to make academic planning. Academic planning is planning in organizing. This stage includes the preparation of activity programs, preparation of academic calendars, lesson schedules, and division of tasks and teacher obligations, Sudarsyah and Nurdin, 2011: 197). To succeed in implementing the curriculum, it must also be supported by reliable facilities and teaching staff.

This is in accordance with research from Onyeachu (2005) which has examined 565 secondary schools in Nigeria regarding curriculum implementation, with the recommendation that in planning curriculum implementation the government must provide facilities and teaching staff according to their competence. Ifedili and Alutu (2011) say from the results of their research that the implementation of education with the 6-3-3-4 system in Nigeria is not successful with indicators of high unemployment rates. According to him, this is because the implementation of the curriculum is not in accordance with the needs of the community. Therefore, in planning the implementation of the curriculum, it must be in accordance with the needs of stakeholders, including the community. Another research review is from Labane (2009) in his research on curriculum implementation in four villages in southern Africa. The background of the research is after 1994 in South Africa, the democratically elected African National Congress (ANC) led government began to introduce changes in the education and 
training system in order to correct the inequality brought about by previous apartheid policies and practices. Although there are many factors that affect the effectiveness (in) implementation, PKBM Miftahul Huda is an educational institution that combines the national curriculum with the Islamic boarding school curriculum. With the implementation of the combined curriculum, it has a significant influence on the development of the number of students at PKBM Miftahul Huda Majalengka which always increases every year. The problems of this research are (1) How is the implementation planning of the community-based education curriculum at PKBM Miftahul Huda Majalengka? (2) How is the academic planning of community-based education at PKBM Miftahul Huda Majalengka? The purpose of this study is to describe and analyze the planning for implementing community-based education curriculum at PKBM Miftahul Huda Majalengka, and to describe and analyze the academic planning of community-based education at PKBM Miftahul Huda Majalengka.

\section{RESEARCH METHODS}

This study uses a qualitative approach with the reason that researchers can describe and obtain data on curriculum implementation planning and academic planning at PKBM Miftahul Huda Majalengka. According to Sugiyono (2011: 21-22) the reason for the qualitative approach is to obtain accurate data according to a natural setting, emphasize more on process, analyze data inductively, and emphasize meaning. The place of research is PKBM Miftahul Huda Majalengka. The data collection techniques used: interviews, observation, and documentation studies. The data validity technique used is source triangulation. The data analysis used the following procedures: data reduction, data presentation, and drawing conclusions (Milles and Hubermans, 1992: 20).

\section{RESULTS AND DISCUSSION}

The curriculum applied at the Miftahul Huda Majalengka PKBM uses a mixed curriculum or modification of the national curriculum combined with the Miftahul Huda Majalengka Taklim Council curriculum. This is done because of the demands of the needs of the surrounding community who want a taklim assembly which also organizes general education. Thus, a curriculum that can accommodate both is needed.

According to Kaharudin (20011) stated that curriculum development can be developed through: 1) the declared vision, 2) the needs of stakeholders, (students, communities, graduate users), and the need for further studies; 3) The results of the evaluation of the previous curriculum and the demands of the development of science and technology and the times; 4) The views of experts with various backgrounds; 5) The trend of the globalization era which requires a person to have a lifelong learning ethos, social literacy, economy, politics, culture and technology.

The curriculum implementation planning includes: syllabus, annual program, semester program, evaluation program, learning implementation plan. has been made by a teacher who is in accordance with his/her field of work. It's just that there are some teachers who do not plan the implementation of the curriculum properly. To support the implementation of the curriculum, academic plans were made at PKBM Miftahul Huda Majalengka, democratically arranged special academic plans in PKBM Miftahul Huda. The step after planning the implementation of the curriculum is to plan the organization of activities through planning academic activities which include making an academic calendar, preparing lesson schedules, setting teacher duties and obligations, as well as school activity programs. Sudarsyah and 
Nurdin, 2011: 197). For supervision in the context of implementing the curriculum, the principal has a supervision schedule and also a regular monthly coaching schedule. This is known from a documentation study in the form of minutes of the KBM coordination meeting in which there is guidance for ustadz or teachers. In this KBM coordination meeting, it can be seen from the attendance list that $85 \%$ attended the meeting invitation. This shows that they are passionate about planning, implementing, and evaluating themselves in implementing the curriculum.

Academic planning at PKBM Miftahul Huda Majalengka is arranged democratically to facilitate curriculum implementation so that the vision and mission that have been formulated can be achieved as well as possible. Academic planning that can be known is the academic calendar, schedule of activities, division of tasks for teachers and employees in educational activities. Especially for the division of teacher tasks in teaching, there are still many teachers who are given tasks that are not in accordance with their competence.

\section{CONCLUSION}

Based on the results of research on community-based education planning at PKBM Miftahul Huda Majalengka, it can be concluded that the curriculum applied at PKBM Miftahul Huda Majalengka uses a mixed curriculum or modification of the national curriculum combined with the curriculum of the Miftahul Huda Majalengka Taklim Council. The curriculum implementation planning is made by the teacher which includes: syllabus, annual program, semester program, evaluation program, learning implementation plan. For teachers who teach general subjects make a complete curriculum implementation plan, while for teachers who teach taklim subjects are not so complete in planning curriculum implementation.

\section{REFERENCES}

Galbraith, W. Michael. 1995 Community-Based Organizations And The Delivery Of Lifelong Learning Opportunities. http://www2. ed.gov/ pubs /PLLI Conf95/comm.html [3 Maret 2012]

Hamalik, Oemar. 2006. Dasar-Dasar Pengembangan Kurikulum. PT Remaja Rosda Karya Bandung: 2006. Kaharudin. 2011.” Peranan Guru dalam Pengembangan Kurikulum”

Moleong, Lexy J., 2011, Metodologi Penelitian Kualitatif, Bandung: Remaja Rosdakarya.

Sarbini dan Lina. 2011. Perencanaan Pendidikan. Bandung: Pusataka Setia Saud,

Udin Syaefudin dan Makmun, Abin Syamsudin. 2009. Perencanaan Pendidikan Suatu Pendekatan Komprehensif. Bandung: PT Remaja Rosda Karya

Sudarsyah dan Nurdin. 2011. Manajemen Pendidikan. Bandung: Alfabeta

Sugiyono. 2011. Metode Penelitian Pendidikan (Pendekatan Kuantitatif, Kualitatif, dan R\&D). Bandung: Alfabeta

Sule, E.S. dan Saefullah, Kurniawan. 2010. Pengantar Manajemen. Jakarta: Kencana Prenada Media Grup 